\title{
Antagonistic Activity of Biocontrol Agents against Rhizoctonia bataticola causing Dry Root Rot (DRR) in Chickpea
}

\author{
Veenashri Jainapur*, Shalini N. Huilgol, S.M. Vastrad and R.B. Jolli
}

Department of Plant Pathology, College of Agriculture (University of Agricultural Sciences, Dharwad), Vijayapura-586101, India

*Corresponding author

\section{A B S T R A C T}

\section{Keywords}

Biocontrol agents, Trichiderma harzianum, Dual culture technique, Paper Towel method

Article Info

Accepted:

12 January 2019

Available Online:

10 February 2019
Among the four bioagents evaluated for their efficacy in inhibiting mycelial growth of Rhizoctonia bataticola causing dry root rot of chickpea by dual culture technique. The results indicated that $T$. harzianum is highly antagonistic to Rhizoctonia bataticola by suppressing its growth by 78.67 per cent. Paper towel method was also followed to test the efficacy of bioagents in suppressing the seedborne infections. Among the four bio-agents with three concentrations viz., $0.4 \%, 0.8 \%$ and $1.2 \%$ tested, as the concentration increased the percent seed infection was reduced, percent germination and vigour index were increased. The Trichiderma harzianum with the concentration of $1.2 \%$ has shown the best result. Seed treatment with Trichoderma harzianum showed least mean seed infection $(13.73 \%)$, higher mean per cent germination $(78.03 \%)$ and high mean vigour index (1461.47).

\section{Introduction}

Control of seed-borne plant pathogens by application of fungicides often gives viable success despite the high cost involvement and risks with toxicity of fungicides. Hence, there is a need to search for alternative methods of control. Biological control through introduction of microorganisms antagonistic to plant pathogens is one of the important strategy in the management of seed-borne plant pathogens. In the present investigation, studies were conducted to know the antagonistic activity of four bio-agents namely Trichoderma harzianum,

Trichoderma viride, Pseudomonas
fluorescens and Bacillus
Rhizoctonia bataticola.

Materials and Methods

\section{In vitro evaluation of bio-agent}

The antagonistic micro-organisms i.e. biocontrol agents like Trichoderma harzianum Rifai., Trichoderma viride Pers., Pseudomonas fluorescens Migula. and Bacillus subtilis Cohn. were evaluated for their antagonistic effect under in vitro condition against Rhizoctonia bataticola by 
dual culture technique. They were also tested for their efficacy in overcoming the seedborne fungal infections in rolled towel method at $0.4,0.8$ and 1.2 per cent concentration.

\section{In vitro evaluation of bio-agent by dual culture technique}

In dual culture, twenty $\mathrm{ml}$ of sterilized and cooled potato dextrose agar was poured in to sterile Petri plates and allowed to solidify. Fungal bioagents were evaluated by inoculating the pathogen at one side of Petri plate and the antagonist inoculated at exactly opposite side of the same plate by leaving 3-4 $\mathrm{cm}$ gap. For this actively growing cultures were used.

In case of evaluation of bacterial bioagents two mycelial discs of pathogens were inoculated and bacterial bioagent was streaked in the centre of the plate. Each treatment was replicated five times. After required period of incubation i.e., after control plates reached $90 \mathrm{~mm}$ diameter, the radial growth of pathogen was measured. Per cent inhibition over control was worked out according to formula given by Vincent (1947).

\section{In vitro evaluation of bio agent by paper} towel method

The powder formulations of antagonists viz., Trichoderma viride, Trichoderma harzianum, Pseudomonas fluorescens and Bacillus subtilis were taken for seed treatment to test their efficacy in overcoming seed borne fungal infections of chickpea under in vitro condition by paper towel method. Seeds of moderately infected chickpea variety JG - 11 were treated with different bio agents at of 0.4 $\left(4 \mathrm{~g} \mathrm{~kg}^{-1}\right), 0.8\left(8 \mathrm{~g} \mathrm{~kg}^{-1}\right)$ and $1.2\left(1.2 \mathrm{~g} \mathrm{~kg}^{-1}\right)$ per cent concentrations. The seeds were shaken along with bio agent for 20 minutes in mechanical shaker for uniform application and then stored in separate boxes for 24 hours. The treated seeds were tested in 4 replication of 100 seeds by employing rolled paper towel method. Seeds without treatment served as control. These paper towels were incubated at $20 \pm 2{ }^{\circ} \mathrm{C}$ for seven days under $12 \mathrm{hrs}$ light and $12 \mathrm{hrs}$ darkness. After seven days of incubation, per cent germination, per cent infection was recorded and seedling vigour index was calculated by taking seedling length (shoot length + root length) $x$ germination percentage (Abdulbaki and Anderson, 1973).

\section{Results and Discussion}

\section{In vitro evaluation of bio-agents by dual culture technique}

The antagonistic micro-organisms like Trichoderma harzianum, Trichoderma viride, Pseudomonas fluorescens and Bacillus subtilis were isolated from the available market formulations and an attempt was made to evaluate these four biocontrol agents for their antagonistic effect against Rhizoctonia bataticola under in vitro conditions by dual culture technique. Inhibition zone in $\mathrm{mm}$ was recorded and per cent inhibition was calculated and the results thus obtained are presented in Table 1. Among the four bioagents tested, maximum inhibition of mycelial growth was noticed in Trichoderma harzianum $(78.67 \%)$ and was found to be significantly superior to Trichoderma viride (73.33 \%). Least inhibition of mycelial growth was observed in Bacillus subtilis (52.22 \%) and followed by Pseudomonas fluorescens $(65.11 \%)$.

\section{In vitro evaluation of bio-agents by paper towel method}

An attempt was made to test the efficacy of four bio-agents, in the management of seed- 
borne infection of chickpea variety JG - 11 at three concentrations viz., $0.4 \%, 0.8 \%$ and 1.2 $\%$ by employing paper towel method as explained under 'Material and Methods' and results are presented in Table 2. Among the four bio-agents tested for their efficacy in the management of seed-borne infection of chickpea, seed treatment with Trichoderma harzianum showed the least per cent seed infection of $11.20,13.20$, and 16.80 at 1.2, 0.8 , and 0.4 per cent concentrations respectively, followed by Trichoderma viride with 20.40, 24.80 and 30.00 at 1.2, 0.8 and 0.4 per cent concentrations respectively. And Relatively more per cent seed infection was noticed in Bacillus subtilis with $38.00,42.80$ and 46.80 at $1.2,0.8$ and 0.4 per cent concentrations respectively, followed by Pseudomonas fluorescens with 30.00, 34.80 and 36.40 at $1.2,0.8$ and 0.4 per cent concentrations respectively. Hence Trichoderma harianum was found superior over other treatments in reducing the per cent seed infection.

Seed treatment with Trichoderma harzianum showed the highest per cent seed germination with $84.40,77.20$ and 72.50 at $1.2,0.8$, and
0.4 per cent concentrations respectively, followed by Trichoderma viride with 81.20, 74.40 and 67.80 at $1.2,0.8$ and 0.4 per cent concentrations respectively. Least per cent seed germination was noticed in Bacillus subtilis with $71.20,66.40$ and 62.80 at 1.2, 0.8 and 0.4 per cent concentrations respectively, followed by Pseudomonas fluorescens with 78.40, 72.00 and 65.60 at 1.2, 0.8 and 0.4 per cent concentrations respectively. Hence Trichoderma harzianum was found superior over other treatments in increasing the per cent seed germination.

Seed treatment with Trichoderma harzianum showed the highest seedling vigour index with $1656.49,1412.58$ and 1315.35 at 1.2 , 0.8 , and 0.4 per cent concentrations respectively, followed by Trichoderma viride with $1460.73,1302.92$ and 1133.16 at $1.2,0.8$ and 0.4 per cent concentrations respectively. And least seedling vigour index was noticed in Bacillus subtilis with 1034.10, 1016.91 and 983.75 at $1.2, \quad 0.8$ and 0.4 per cent concentrations respectively, followed by Pseudomonas fluorescens with 1197.95, 1165.82 and 1015.11 at $1.2,0.8$ and 0.4 per cent concentrations respectively.

Table.1 In vitro evaluation of biocontrol agents against $R$. bataticola

\begin{tabular}{|c|l|c|}
\hline Sl. No. & \multicolumn{1}{|c|}{ Bioagents } & Per cent inhibition \\
\hline $\mathbf{1}$ & Trichoderma harzianum & 78.67 \\
& & $(62.49)^{*}$ \\
\hline $\mathbf{2}$ & Trichoderma viride & 73.33 \\
& & $(58.91)$ \\
\hline $\mathbf{3}$ & Pseudomonas fluorescens & 65.11 \\
& & $(58.80)$ \\
\hline $\mathbf{4}$ & Bacillus subtilis & 52.22 \\
& & $(46.27)$ \\
\hline & S. Em. \pm & 0.29 \\
\hline & C.D. at 1 \% & 0.81 \\
\hline
\end{tabular}

*Figures in the parenthesis indicates the angular transformed value 
Table.2 In vitro evaluation of bioagents against seed mycoflora of chickpea by Paper towel method

\begin{tabular}{|c|c|c|c|c|c|c|c|c|c|c|c|c|}
\hline \multirow[t]{3}{*}{ Bioagent (B) } & \multirow{2}{*}{\multicolumn{4}{|c|}{$\begin{array}{l}\text { Per cent seed infection } \\
\text { Concentration }(\mathrm{C})\end{array}$}} & \multirow{2}{*}{\multicolumn{4}{|c|}{$\begin{array}{l}\text { Per cent seed germination } \\
\text { Concentration }(\mathrm{C})\end{array}$}} & \multicolumn{4}{|c|}{ Vigour index } \\
\hline & & & & & & & & & \multicolumn{4}{|c|}{ Concentration (C) } \\
\hline & \multicolumn{4}{|c|}{$\begin{array}{l}\text { Concentration (C) } \\
0.8 \% \\
\end{array}$} & $0.4 \%$ & $0.8 \%$ & $1.2 \%$ & Mean & $0.4 \%$ & $0.8 \%$ & $1.2 \%$ & Mean \\
\hline Trichoderma harzianum & $\frac{16.80}{(24.20)^{*}}$ & $\frac{13.20}{(21.30)}$ & $\frac{11.20}{(19.55)}$ & $\frac{13.73}{(21.75)}$ & $\frac{72.50}{(58.37)}$ & $\frac{77.20}{(61.48)}$ & $\frac{84.40}{(66.74)}$ & $\frac{78.03}{(62.05)}$ & 1315.35 & 1412.58 & 1656.49 & 1461.47 \\
\hline Trichoderma viride & $\begin{array}{c}30.00 \\
(33.21)\end{array}$ & $\begin{array}{c}24.80 \\
(29.87)\end{array}$ & $\begin{array}{c}20.40 \\
(26.85)\end{array}$ & $\begin{array}{l}25.05 \\
(29.97)\end{array}$ & $\begin{array}{c}67.80 \\
(55.43)\end{array}$ & $\begin{array}{c}74.40 \\
(59.60)\end{array}$ & $\begin{array}{c}81.20 \\
(64.30)\end{array}$ & $\begin{array}{c}74.47 \\
(59.65)\end{array}$ & 1133.16 & 1302.92 & 1460.73 & 1298.93 \\
\hline Pseudomonas fluorescens & $\begin{array}{c}36.40 \\
(37.11)\end{array}$ & $\begin{array}{c}34.80 \\
(36.15)\end{array}$ & $\begin{array}{c}30.00 \\
(33.21)\end{array}$ & $\begin{array}{c}33.73 \\
(35.49)\end{array}$ & $\begin{array}{c}65.60 \\
(54.09)\end{array}$ & $\begin{array}{c}72.00 \\
(58.05)\end{array}$ & $\begin{array}{c}78.40 \\
(62.31)\end{array}$ & $\begin{array}{c}72.00 \\
(58.05)\end{array}$ & 1015.11 & 1165.82 & 1197.95 & 1126.29 \\
\hline Bacillus subtilis & $\begin{array}{c}46.80 \\
(43.17)\end{array}$ & $\begin{array}{c}42.80 \\
(40.86)\end{array}$ & $\begin{array}{c}38.00 \\
(38.06)\end{array}$ & $\begin{array}{c}42.53 \\
(40.69)\end{array}$ & $\begin{array}{c}62.80 \\
(52.42)\end{array}$ & $\begin{array}{c}66.40 \\
(54.57)\end{array}$ & $\begin{array}{c}71.20 \\
(57.54)\end{array}$ & $\begin{array}{c}66.80 \\
(54.82)\end{array}$ & 983.75 & 1016.91 & 1034.10 & 1011.58 \\
\hline Control & $\begin{array}{c}50.60 \\
(45.34)\end{array}$ & $\begin{array}{c}53.26 \\
(46.87)\end{array}$ & $\begin{array}{c}56.17 \\
(48.54)\end{array}$ & $\begin{array}{c}53.34 \\
(46.92)\end{array}$ & $\begin{array}{c}61.20 \\
(51.47)\end{array}$ & $\begin{array}{c}62.45 \\
(52.51)\end{array}$ & $\begin{array}{c}65.40 \\
(53.97)\end{array}$ & $\begin{array}{c}63.02 \\
(52.54)\end{array}$ & 725.56 & 755.06 & 785.06 & 755.22 \\
\hline Mean & $\begin{array}{c}36.12 \\
(36.58)\end{array}$ & $\begin{array}{c}33.24 \\
(34.68)\end{array}$ & $\begin{array}{c}30.04 \\
(32.60)\end{array}$ & & $\begin{array}{c}63.52 \\
(52.85)\end{array}$ & $\begin{array}{c}70.24 \\
(57.06)\end{array}$ & $\begin{array}{c}75.28 \\
(60.47)\end{array}$ & & 1047.11 & 1130.01 & 1214.91 & \\
\hline & (B) & (C) & B X & $\mathbf{C}$ & (B) & (C) & B Y & $\mathbf{C}$ & (B) & (C) & & \\
\hline S. Em. \pm & 0.56 & 0.43 & 0. & & 0.51 & 0.40 & 0. & 39 & 6.87 & 5.32 & & \\
\hline C.D. at $1 \%$ & 1.62 & 1.26 & $2 . \varepsilon$ & & 1.48 & 1.15 & & 57 & 19.83 & 15.36 & & \\
\hline
\end{tabular}

*Figures in the parenthesis indicates the angular transformed values 
Seed treatment with Trichoderma harzianum has shown superiority over other bioagents, within the Trichoderma harzianum concentrations the $1.2 \%$ has shown the best results. Seed treatment with Trichoderma harzianum shown least mean seed infection $(13.73 \%)$, higher mean per cent germination $(78.03 \%)$ and mean high vigour index (1461.47). followed by Trichoderma viride per cent mean seed infection(25.06), per cent mean seed of germination (74.47) and seedling vigour index(1298.93). Seed treatment with Bacillus subtilis was found ineffective, with highest 42.53 per cent mean seed infection, with least 66.80 per cent mean germination and 1011.58 vigour index followed by Seed treatment with Pseudomonas fluorescens with 33.37 per cent mean seed infection, with least 72.00 per cent mean germination and 1126.29 vigour index.

The present findings are in agreement with, Choudhary et al., (2010) tested four bioagents viz., Trichoderma viride, Trichoderma harzianum, Aspergillus versicolor and Bacillus firmus for the control of dry root rot in mungbean. In dual cultures, Trichoderma viride, Trichoderma harzianum and Aspergillus versicolor were effective in inhibiting the growth of Macrophomina phaseolina to an extent of 61 to $65 \%$. Similarly Khan and Khan (2015) studied the seed treatment with bio-fungicides for management of dry root rot of Chick pea caused by Macrophomina phaseolina. Seed treatment with bio-wilt X (Trichoderma harzianum) reduced the severity to 2.4 on $0-5$ scale followed by bio-derma (T. viride, 2.7) and Abtec Pseudo (Pseudomonas fluorescens, 2.8). The functional nodule count decreased while an increase in non functional nodules was recorded due to inoculation with Macrophomina phaseolina.

\section{References}

Abdualbaki, A. A. and Anderson, J. P., 1973, Vigour determination in soybean seeds by multiple criteria. J.Crop sci., 13: 630-633.

Choudhary, S., Pareek, S. and Saxena J., 2010, Efficacy of biocontrol agents singly and in combinations against dry root rot (Macrophomina phaseolina) of mungbean. J. of Mycol. and Pl.Pathol., 40 (1):141-144.

Khan, U. and Khan, M. R., 2015, Seed treatment with bio-fungicides for management of dry root rot of Chick pea caused by Macrophomina phaseolina. Department of Plant Protection, Faculty of Agricultural Sciences, Aligarh Muslim University, Aligarh 202 002, India.

Vincent, J. M., 1947, Distortion of fungal hyphae in the presence of certain inhibitors. J. Nat., 159: 850.

\section{How to cite this article:}

Veenashri Jainapur, Shalini N. Huilgol, S.M. Vastrad and Jolli, R.B. 2019. Antagonistic Activity of Biocontrol Agents against Rhizoctonia bataticola causing Dry Root Rot (DRR) in Chickpea. Int.J.Curr.Microbiol.App.Sci. 8(02): 1591-1595.

doi: https://doi.org/10.20546/ijcmas.2019.802.186 